\title{
Estimated dietary intake of essential elements from four selected staple foods in Najran City, Saudi Arabia
}

\author{
Hatem Mohamed ${ }^{1}$, Parvez I. Haris ${ }^{1}$ and Eid I. Brima ${ }^{2^{*} \text { (D) }}$
}

\begin{abstract}
The estimated dietary intake (EDI) of essential elements selenium (Se), zinc (Zn), manganese (Mn) and copper (Cu) has not been previously investigated for Najran city, Saudi Arabia. This type of information can be valuable for protecting public health. The aim of this study was to estimate the EDI of these elements. A food frequency questionnaire (FFQ) was completed by the study participants $(n=80)$ to obtain dietary intake of selected staple foods (rice, wheat, meat and chicken). The concentrations of $\mathrm{Se}, \mathrm{Zn}, \mathrm{Mn}$ and $\mathrm{Cu}$ in these staple foods were determined using inductively coupled plasma-mass spectrometry (ICP-MS). The ranges of concentrations ( $\mathrm{mg} / \mathrm{kg}$, wet weight) were as follows: Se (0.07-0.24), Zn (3.91-20.89), Mn (0.63-14.69) and Cu (0.69-2.41). The calculated ranges of EDls (mg/kg bw/day) for the essential elements were as follows: Se $9.55 \times 10^{-5}-5.75 \times 10^{-4}$, Zn $1.33 \times 10^{-2}-5.83 \times 10^{-2}, \mathrm{Mn} 1.49 \times 10^{-3}$ $3.31 \times 10^{-2}$, Cu $1.65 \times 10^{-3}-5.42 \times 10^{-3}$. The highest EDI for Cu and Mn came from wheat. In the case of Se and $\mathrm{Zn}$, the foods that contributed the highest EDI were chicken and meat, respectively. The lowest EDIs were found for Se in wheat, $\mathrm{Zn}$ in rice and both $\mathrm{Mn}$ and $\mathrm{Cu}$ in chicken. The percentages (\%) of provisional maximum tolerable daily intake (PMTDI) for Se, Zn, Mn and Cu were 13\%, 11\%, 14\% and 3.4\%, respectively when contributions from all the four classes of foods were combined. The percentage of the recommended daily allowance (RDA) derived from these foods were $80 \%, 20 \%, 17 \%$ and $5.6 \%$ for Se, Zn, Mn and Cu were, respectively. This raises the possibility of Cu deficiency in the Najran population. However, a total diet study and human biomonitoring study is needed in the future to fully assess if people in Najran city are at risk of deficiency or excessive exposure to trace elements.
\end{abstract}

Keywords: EDI, ICP-MS, Essential elements, Rice, Wheat, Meat, Chicken, Najran, Saudi Arabia

\section{Introduction}

Nutrition is an essential factor in health and disease [1]. The patterns of nutritional disorders in the developing world are further complicated by sociological changes, which can take place due to urbanisation and changing lifestyles [2]. Foods contain both essential and toxic elements that have significant effects on human health [3]. The human body needs different types of trace elements to perform nutritional, metabolic, and hormonal functions. The level of exposure to different elements depends

\footnotetext{
*Correspondence: ebrahim65@gmail.com

${ }^{2}$ Department of Chemistry, College of Science, King Khalid University, Abha 61413, Saudi Arabia

Full list of author information is available at the end of the article
}

on their intake, concentrations and distribution in foods [4].

Essential elements have beneficial health effects on human body and help in maintaining normal and complex physiological functions of the human body [5]. Essential elements such as $\mathrm{Se}, \mathrm{Zn}, \mathrm{Mn}, \mathrm{Cu}$ and other major elements play important roles in human biology, physiology, metabolism and enzyme processes [5, 6]. Small quantities of essential elements are vital for human body's growth and development, and they can be obtained through a balanced diet $[5,6]$.

An excessive intake or deficiency of essential elements may lead to health problems in human [5-7]. For instance, an excessive intake of Se leads to neurological disorders and generalised weakness [8], whereas 
deficiency in Se is associated with Kashin-Beck disease, cardiovascular diseases, hypothyroidism and weakened immune system [9-11]. It has been reported that excessive intake of $\mathrm{Zn}$ can lower the high-density lipoprotein (HDL) levels among healthy males [12]. Zn deficiency in humans is linked to loss of appetite, infant growth retardation, skin changes and immunological abnormalities [13]. In the case of Mn, excessive intake can cause health problems such as growth retardation, nausea and muscle weakness [14], whereas manganese deficiency is associated with changes in hair colour and loss of weight [15]. Similarly, long-term exposure to elevated levels of copper can lead to various conditions including Wilson's disease and acute gastrointestinal problems [16]. Copper deficiency causes a range of disorders including anaemia, lymphoma, myelodysplastic syndrome and neutropenia [17].

Rice is a staple food for many populations in the world [18]. Rice is rich in micronutrients such as oryzanols, tocopherols, tocotrienols, phytosterols and dietary fibres like beta-glucan, pectin and gum [19]. Rice is grown in more than 100 countries, and there are different types of rice accounting for about $25 \%$ of the world's food grain production including in continents such as Asia, Africa and America [20]. The elemental composition of the rice grain is potentially a critical factor that has an impact on human health. High consumption of white rice is associated with a significantly increased risk of Type 2 diabetes, mainly among Asian populations [21]. In Saudi Arabia, rice is considered as the dominant food source, and the per capita consumption is estimated at $42 \mathrm{~kg} /$ year [22].

Wheat grain is regarded as the second primary human food, after rice [23]. This cereal is composed of several different tissues, the germ, the endosperm, the thick cellwalled aleurone layer and the pericarp [23]. Wheat grains are also a major source of almost all vitamins including B-group vitamins, thiamine, riboflavin, niacin, pantothenic acid, pyridoxine, biotin, vitamin $\mathrm{E}$ and the carotenoids [24]. However, wheat consumption can also cause allergy in humans [25]. In Saudi Arabia, wheat consumption has increased by $2 \%$ in the period between the year 2011 and 2013 [26].

Meat is one of the essential food sources to humans and supplies the human body with proteins, amino acids and other essential minerals, required for tissue formation, growth and repair [27]. However, high intake of red meat has been linked to different diseases including cardiovascular disease, cancer and diabetes [28].

Chicken is one of the main staple foods in the world and represents a rich source of essential elements [29]. However, poultry meat can also be a source of exposure to pathogenic microbes and heavy metals $[29,30]$. The consumption of beef and lamb in Saudi Arabia has decreased in the period 1985-2010 [26]. In contrast, the consumption of poultry has increased, and the Saudis consume $41.6 \mathrm{~kg}$ per capita of chicken annually [31].

From a public health perspective, it is crucial to assess the Saudis exposure to essential and toxic elements as they may play a role in the development of chronic diseases, which are on the rise in the Kingdom [32]. In Saudi Arabia in general, and in Najran city in particular, there is a lack of studies investigating the content of essential elements in the main staple foods and most of the previous studies had focused on calories and carbohydrate intake [33-35]. However, some recent studies are beginning to address this issue including studies on selected food from Saudi market and evaluation of trace metals in commonly consumed food in Saudi Arabia [36, 37].

This is the first study to investigate the concentration of essential elements in rice, wheat, red meat and chicken that are sold in markets in Najran city (Saudi Arabia) that are consumed by the local population. This study aimed to determine the estimated dietary intakes (EDIs) for the essential elements $\mathrm{Se}, \mathrm{Zn}, \mathrm{Mn}$, and $\mathrm{Cu}$ in these main staple foods of the people in Najran city. The findings will be valuables for providing nutritional facts and information about the essential elements in these foods to improve the health of the Najran population and other regions of Saudi Arabia.

\section{Materials and methods}

All aspects of the current study including location, study population, food consumption and average daily intake, collection of food samples, pre-treatment of food samples, digestion of food samples, elemental analysis and analytical method employed in the current study were same as reported in the recently published study for EDI of toxic elements [38]. Briefly, the study location was in Najran city in the south of Saudi Arabia, where 25 food samples of rice, wheat, loin of cooked meat (cow, sheep, goat and camel) and cooked breast of chicken were collected from a local market (El-Faisaliya market of Najran city). Food samples were analysed by using Inductively Coupled Plasma-Mass Spectrometry (ICP-MS) in Abha city at King Khalid University. For this study, ICP-MS was used for the analysis of essential trace elements in foods because it has a lower detection limit and high efficiency compared to techniques such inductively coupled plasma optical emission spectrometry (ICP-OES) or atomic absorption spectroscopy (AAS).

Additionally, a food frequency questionnaire (FFQ), the questionnaire comprises of simple questions to avoid the occurrence of misinterpreted questions. This step was followed by conducting a pilot test of the questionnaire by asking a group of 20 students and academic of Najran University to complete the questionnaire. The 
Table 1 Demographic details of 80 participants from Najran city including gender age and other parameters

\begin{tabular}{|c|c|c|}
\hline Demographic data $(\mathrm{N}=80)$ & Frequency & Percent (\%) \\
\hline \multicolumn{3}{|l|}{ Gender } \\
\hline Male & 36 & 45.00 \\
\hline Female & 44 & 55.00 \\
\hline \multicolumn{3}{|l|}{ Age (years) } \\
\hline$(18-39)$ & 40 & 50.00 \\
\hline$(40-59)$ & 30 & 37.50 \\
\hline$(60-79)$ & 10 & 12.50 \\
\hline \multicolumn{3}{|l|}{ Marital status } \\
\hline Single & 26 & 32.50 \\
\hline Married & 44 & 55.00 \\
\hline Divorced & 3 & 3.80 \\
\hline Widowed & 7 & 8.80 \\
\hline \multicolumn{3}{|l|}{ Education } \\
\hline Illiterate & 10 & 12.50 \\
\hline School level & 25 & 31.30 \\
\hline University & 43 & 53.80 \\
\hline Post-University & 2 & 2.50 \\
\hline \multicolumn{3}{|l|}{ Occupation } \\
\hline Government employee & 24 & 30.00 \\
\hline Private sector employee & 17 & 21.30 \\
\hline Student & 9 & 11.30 \\
\hline Housewife & 10 & 12.50 \\
\hline Unemployed & 19 & 23.80 \\
\hline Other & 1 & 1.30 \\
\hline \multicolumn{3}{|l|}{ Monthly income } \\
\hline SAR $<4000$ & 46 & 57.50 \\
\hline SAR 4000-7000 & 14 & 17.50 \\
\hline SAR $7000-10,000$ & 15 & 18.80 \\
\hline SAR $10,000+$ & 5 & 6.30 \\
\hline
\end{tabular}

questionnaire was used to collect information from the 80 participants, a written consent was obtained from the participants in the study. The first section of the FFQ was used to collect information on socio-demographical variables including gender, age, marital status, occupation and educational status. The demographic parameters covered include gender, age group, marital status and educational level. The majority of the study population (55\%) were females. The range of age is between 18 and 39 years for $50 \%$ of all the participants. Most of the studied population (57.5\%) had a monthly income of SAR < 4000; more information is presented in Table 1.

The FFQ included questions about portion sizes (in grams) of the different foods and consumption frequencies are presented in Table 2. Ethical approvals for the study were obtained from both De Montfort University (HLSFREC Ref: 1180) and Najran University ethics committee (23rd May 2013) before the beginning of the study.

\section{Analytical method}

The analysis was carried out identically to that reported in a recent study [38]. Multi-element calibration standards were used and included the four elements (Se, Zn, $\mathrm{Mn}$ and $\mathrm{Cu}$ ) at concentrations of 0.0, 1.0, 5.0, 10.0, 20.0 and $40.0 \mu \mathrm{g} / \mathrm{L}$. Furthermore, an internal standard (scandium) was introduced online with a concentration of $100 \mu \mathrm{g} / \mathrm{L}$. For quality control, a mixed standard $(20 \mu \mathrm{g} / \mathrm{L})$ of the measured elements was measured in each experiment after every five samples within the batch. The data processing was undertaken using Qtegra software (Thermo Fisher Scientific, Waltham, MA, USA).

\section{Quality control and quality assurance}

The quality control for this study was performed by measuring known mixed concentrations $(20 \mu \mathrm{g} / \mathrm{L})$ of $\mathrm{Se}, \mathrm{Zn}, \mathrm{Mn}$ and $\mathrm{Cu}$ after every five samples. A mixed

Table 2 Intake of different foods in Saudi Arabia estimated from the FFQ

\begin{tabular}{|c|c|c|c|}
\hline No. & Food type & $\begin{array}{l}\text { Najran city (this } \\
\text { study) }\end{array}$ & Saudi Arabia (other studies) \\
\hline 1 & Rice & $243 \mathrm{~g}$ & 160 g_Riyadh City_Al-Kanhal et al. (1999) [65] \\
\hline 2 & Wheat & $161 \mathrm{~g}$ & 298 g_Riyadh City_Nigatu et al. (2015) [66] \\
\hline 3 & Meat & $199.8 \mathrm{~g}$ & $\begin{array}{l}75 \mathrm{~g} \text {-All thirteen administrative regions of Saudi Arabia_Moradi-Lakeh et al. (2017) [67] } \\
116.69 \mathrm{~g} \text {-Riyadh City_Al-Othman et al. (2012) [60] } \\
47.60 \mathrm{~g} \text {-Jeddah City_Al-Ahmary (2009) [57] }\end{array}$ \\
\hline 4 & Chicken & $170.4 \mathrm{~g}$ & $75 \mathrm{~g}$-All thirteen administrative regions of Saudi Arabia_Moradi-Lakeh et al. (2017) [67] \\
\hline 5 & Vegetables & $195 \mathrm{~g}$ & $\begin{array}{l}105 \mathrm{~g} \text {-All thirteen administrative regions of Saudi Arabia_Moradi-Lakeh et al. (2017) [67] } \\
203 \mathrm{~g} \text {-Riyadh City-Al-Othman et al. (2012) [60] }\end{array}$ \\
\hline 6 & Fruits & $149.5 \mathrm{~g}$ & $\begin{array}{l}103 \mathrm{~g} \text {-All thirteen administrative regions of Saudi Arabia_Moradi-Lakeh et al. (2017) [67] } \\
90.54 \mathrm{~g} \text {-Riyadh City_Al-Othman et al. (2012) [60] } \\
289.50 \mathrm{~g} \text { —-Jeddah City_Al-Ahmary (2009) [57] }\end{array}$ \\
\hline 7 & Fish & $28.1 \mathrm{~g}$ & $75 \mathrm{~g}$-All thirteen administrative regions of Saudi Arabia—Moradi-Lakeh et al. (2017) [67] \\
\hline 8 & Date & $173 \mathrm{~g}$ & $\begin{array}{l}95.34 \mathrm{~g} \text {-All regions of Saudi Arabia_Al-Shreed et al. (2012) [66] } \\
100 \mathrm{~g} \text {-All regions of Saudi Arabia—Kamel et al. (2007) [69] }\end{array}$ \\
\hline
\end{tabular}


Table 3 Provisional Tolerable Weekly Intake (PTWI) of Essential Elements (Se, Zn, Mn and Cu) and their provisional maximum tolerable daily intake (PMTDI)

\begin{tabular}{lllll}
\hline No. & Elements & PTWI & PMTDI & References \\
\hline 1 & Selenium (Se) & $66 \mu \mathrm{g} / \mathrm{kg} \mathrm{bw} /$ week & $9.4 \mu \mathrm{g} / \mathrm{kg} \mathrm{bw} /$ day & JECFA;WHO, 72 (2011) [70] \\
2 & Zinc (Zn) & $7 \mathrm{mg} / \mathrm{kg} \mathrm{bw} /$ week & $1 \mathrm{mg} / \mathrm{kg} \mathrm{bw/day}{ }^{\mathrm{a}}$ & JECFA; WHO, 26 (1982) [71] \\
3 & Manganese (Mn) & $2.5 \mathrm{mg} / \mathrm{kg} \mathrm{bw} /$ week & $0.36 \mathrm{mg} / \mathrm{kg} \mathrm{bw} /$ day & JECFA;WHO, 26 (1982) [72] \\
4 & Copper (Cu) & $3.5 \mathrm{mg} / \mathrm{kg} \mathrm{bw/week}$ & $0.5 \mathrm{mg} / \mathrm{kg} \mathrm{bw/day}{ }^{\mathrm{a}}$ & JECFA;WHO, 26 (1982) [73] \\
\hline
\end{tabular}

${ }^{a}$ Calculated value based on PTWDI

concentration of each element $(20 \mu \mathrm{g} / \mathrm{L})$ was spiked into randomly selected rice samples, and the recoveries for all measured elements were reported. For quality assurance, a certified reference material, NIES Certified Reference Material, Rice Flour-Unpolished, Low Level (Cd) (No10a NIES), was also measured.

\section{Health risk assessment for humans and estimated dietary intake calculation}

Concentrations and EDIs were calculated for each element in the four staple foods based on the method described in a recent publication [38]. Briefly, the daily intake of each measured element in food was calculated based on the following equation:

$$
\mathrm{DI}(\mu \mathrm{g})=\mathrm{D}(\mathrm{g}) \times \mathrm{Cc}(\mu \mathrm{g} / \mathrm{g})
$$

where $\mathrm{DI}$ is the daily intake; $\mathrm{D}(\mathrm{g})=\mathrm{D}$ is the average daily intake in all the food types (in g/day) and Cc is the calculated concentration $(\mu \mathrm{g} / \mathrm{g})$.

EDIs were expressed in $\mathrm{mg} / \mathrm{kg}$ bw day was calculated as in the following equation:

$$
\mathrm{EDI}=(\mathrm{DI}(\mu \mathrm{g}) / \mathrm{kg} \mathrm{bw}) / 1000=\mathrm{mg} / \mathrm{kg} \text { bw day }
$$

where bw is the average body weight (in $\mathrm{kg}$ ), average body weight in this study is $71.53 \mathrm{~kg}$ based on the data obtained from the participating volunteers. The calculation of the EDI is the same as the provisional maximum tolerable daily intake (PMTDI). The PMTDI value represents permissible human exposure of substance in food and drinking water [39].

Hazard quotients (HQs) for $\mathrm{Se}, \mathrm{Zn}, \mathrm{Mn}$, and $\mathrm{Cu}$ in all 25 samples were calculated based on the following equation:

$$
\text { HQ }=\text { EDIcalc/PMTDI. }
$$

In Eq. (3), EDIcalc is the EDI found in this study, and PMTDI is the provisional maximum tolerable daily intake (PMTDI) established by the WHO [40-43]. The PMTDIs are presented in Table 3.

\section{Results}

\section{Quality control and quality assurance results}

The recoveries for all measured elements in mixed quality control standard, which was measured after every five samples and was measured five times per batch $(n=15)$. The recoveries were as follows: Se (95.93\%), Zn (97.60\%), $\mathrm{Mn}(95.55 \%)$ and $\mathrm{Cu}(119.43 \%)$. Spiked recoveries were as follows: Se (99.86\%), Zn (89.08\%), Mn (99.09\%) and $\mathrm{Cu}(100.96 \%)$. The result of the CRM (No.10a NIES) were as follows: Se (certified value 0.06, measured value $0.10 \pm 0.01 \mu \mathrm{g} / \mathrm{g}$ ), $\mathrm{Zn}$ (certified value $25.2 \pm 0.8 \mu \mathrm{g} / \mathrm{g}$, measured value $24.00 \pm 0.03 \mu \mathrm{g} / \mathrm{g}$ ), Mn (certified value $34.7 \pm 1.8 \mu \mathrm{g} / \mathrm{g}$, measured value $23.39 \pm 0.08 \mu \mathrm{g} / \mathrm{g})$ and $\mathrm{Cu}$ (certified value $3.5 \pm 0.3 \mu \mathrm{g} / \mathrm{g}$, measured value $3.37 \pm 0.04 \mu \mathrm{g} / \mathrm{g})$.

\section{Concentration of Se, $\mathrm{Zn}, \mathrm{Mn}$, and $\mathrm{Cu}$ in the four selected staple foods}

The concentrations of the four essential elements (Se, $\mathrm{Zn}, \mathrm{Mn}$ and $\mathrm{Cu}$ ) were determined in the four selected staple foods samples. There is a substantial difference in the concentration of the four food minerals amongst the four selected four staple foods. Meat was found to have a high concentration of $\mathrm{Zn}(20.89 \mathrm{mg} / \mathrm{kg})$. The highest $\mathrm{Mn}(14.69 \mathrm{mg} / \mathrm{kg})$ concentration was found in wheat. The concentrations of Se $(0.04 \mathrm{mg} / \mathrm{kg})$ and $\mathrm{Cu}(0.69 \mathrm{mg} / \mathrm{kg})$ were observed to be relatively low in wheat and chicken, respectively. The mean concentrations of $\mathrm{Se}, \mathrm{Zn}, \mathrm{Mn}$, and $\mathrm{Cu}(\mathrm{mg} / \mathrm{kg})$ in the 25 samples of rice, wheat, red meat and chicken are presented in Table 4.

\section{Daily intake (DI) of essential elements}

The average DI ( $\mu \mathrm{g} /$ day) of $\mathrm{Se}, \mathrm{Zn}, \mathrm{Mn}$, and $\mathrm{Cu}$ estimated from the four food categories (rice, wheat, meat and chicken) for an adult Najran person are reported in Table 5. The mean average DI ( $\mu \mathrm{g} /$ day) was 23.96 , 2401.38, 887.05 and 282.25 for $\mathrm{Se}, \mathrm{Zn}, \mathrm{Mn}$ and $\mathrm{Cu}$, respectively. In the case of $\mathrm{Zn}$, meat provides the highest intake of this element out of the four selected staple foods in this study (4173.55 $\mu \mathrm{g} /$ day). Furthermore, the daily intake of Se was the lowest from wheat $(6.83 \mu \mathrm{g} /$ day $)$, whereas $\mathrm{Mn}$ and $\mathrm{Cu}$ had the highest daily intake from wheat amongst the four staple foods. Data presented in 
Table 4 Mean concentrations ( $\mu \mathrm{g} / \mathrm{g}$ ) mean \pm SD of elements (Se, $\mathrm{Zn}, \mathrm{Mn}$ and $\mathrm{Cu}$ ) measured in 25 samples of the four food types (rice, wheat, meat and chicken) in dry weight samples: rice $(n=8)$, wheat $(n=5)$, meat $(n=4)$ and chicken $(n=8)$

\begin{tabular}{llllrrr}
\hline No. & Food type & Average: $\left(\frac{\text { Dryweight }}{\text { Wetweight }}\right)$ & \multicolumn{2}{l}{ Essential elements $(\boldsymbol{\mu g} / \mathbf{g})$} & & \\
\cline { 5 - 7 } & & & Se & Zn & Mn & Cu \\
\hline 1 & Rice & 0.92 & $0.13 \pm 0.09$ & $9.26 \pm 4.20$ & $10.07 \pm 11.87$ & $0.8 \pm 0.32$ \\
2 & Wheat & 0.88 & $0.19 \pm 0.11$ & $18.99 \pm 6.97$ & $24.53 \pm 9.89$ & $1.47 \pm 0.65$ \\
3 & Meat & 0.26 & $0.06 \pm 0.01$ & $11.58 \pm 1.58$ & $0.17 \pm 0.07$ & $0.16 \pm 0.10$ \\
4 & Chicken & 0.39 & $0.62 \pm 0.14$ & $18.42 \pm 3.19$ & $1.60 \pm 1.13$ & $1.77 \pm 0.38$ \\
\hline
\end{tabular}

Average of dry weight/wet weight was also reported

Table 5 Dietary intake (DI) of the essential element (Se, $\mathrm{Zn}, \mathrm{Mn}$ and $\mathrm{Cu}$ ) in $\mathbf{2 5}$ samples of the four food types (rice, wheat, meat and chicken)

\begin{tabular}{lcccc}
\hline \multicolumn{5}{l}{ Dl of the essential elements $(\boldsymbol{\mu g} /$ day $)$} \\
\hline Food type & Se & $\mathbf{Z n}$ & Mn & $\mathbf{C u}$ \\
\hline Rice & 37.5 & 2502.5 & 2667.5 & 215.0 \\
Wheat & 25.5 & 1364.3 & 2118.8 & 121.5 \\
Meat & 48.0 & 9456.0 & 132.0 & 108.0 \\
Chicken & 138.6 & 4274.6 & 437.8 & 413.6 \\
Water $^{\text {a }}$ & 2.83 & 94.10 & 0.18 & 1.73 \\
Total & 252.43 & 17.691 .5 & 5356.28 & 859.83 \\
\hline
\end{tabular}

a Data taken from Brima study 2017

Table 5 also show that the overall highest DI of $\mathrm{Zn}$ comes from meat, followed by wheat.

\section{Estimated provisional maximum tolerable daily intakes (PMTDI)}

Figure 1 presents the percentages (\%) of the estimated provisional maximum tolerable daily intakes (PMTDI) for $\mathrm{Se}, \mathrm{Zn}, \mathrm{Mn}$ and $\mathrm{Cu}$. The percentages (\%) PMTDI explain the contributions from each food class and all food classes combined for each element. For each of the elements, the \% PMTDI is above $11 \%$, except for $\mathrm{Cu}$. The lowest percentage of the PMTDI is seen for $\mathrm{Cu}$ with $3.4 \%$ when contributions from all the four classes of foods are combined.

\section{Estimated dietary intake (EDI) and recommended daily} allowance (RDA) of essential elements

Table 6 illustrates the estimated dietary intake (EDI) of essential elements and the hazard quotient (HQ) for $\mathrm{Se}, \mathrm{Zn}, \mathrm{Mn}$ and $\mathrm{Cu}$. The decreasing order of EDIs (mg/ $\mathrm{kg}$ bw/day) was as follows: $\mathrm{Zn}\left(5.83 \times 10^{-2}\right)$ in meat, $\mathrm{Mn}$ $\left(3.31 \times 10^{-2}\right)$ in wheat, $\mathrm{Cu}\left(5.42 \times 10^{-3}\right)$ in wheat and Se $\left(5.75 \times 10^{-4}\right)$ in chicken. The HQ for each of the essential elements does not exceed one.

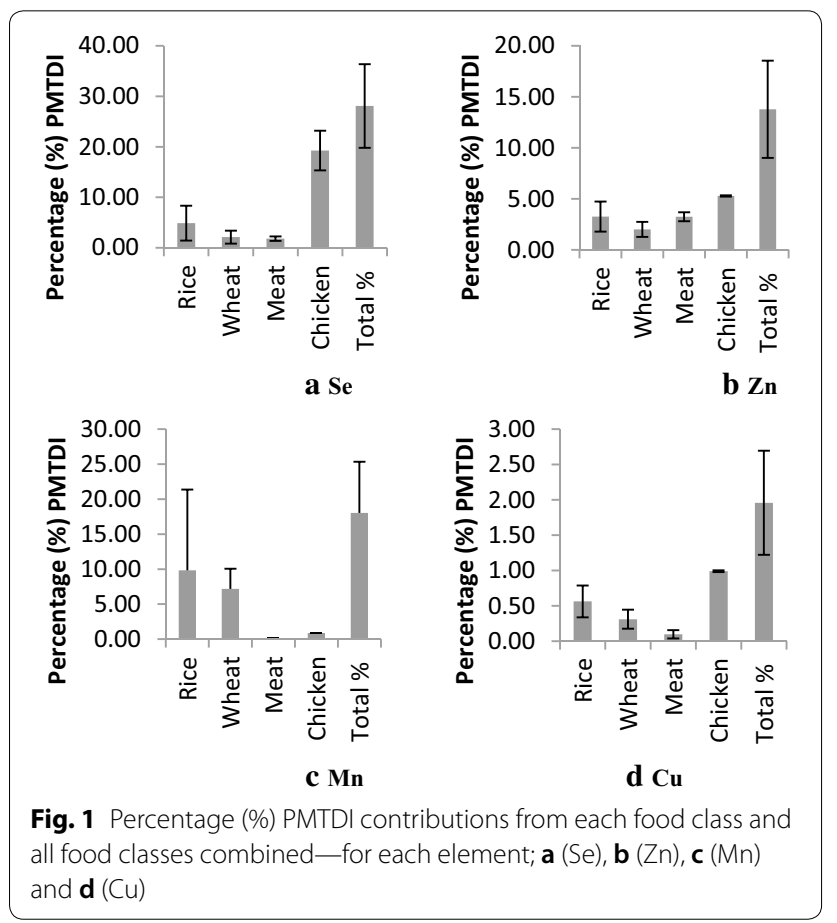

Figure 2 presents the four measured essential elements (Se, $\mathrm{Zn}, \mathrm{Mn}$ and $\mathrm{Cu}$ ) in the four common staple foods regarding average daily intake. The daily intake of each of the four elements for each of the four foods was calculated. As can be seen, the four foods analysed supplies more than $2401.38 \mu \mathrm{g} /$ day of $\mathrm{Zn}$. These findings come as a result of a higher daily dietary intake from chicken, followed by meat. The provisional maximum tolerable daily intake (PMTDI \%) for the measured elements was calculated. Mn has the highest PMTDI (14\%) followed by Se (13\%). Copper has the lowest PMTDI that contributed to $3.4 \%$ of the total PMTDI. Taking into considerations the daily intakes measured for the investigated elements, the percentage of the RDAs, derived from the four foods (rice, wheat, meat and chicken), for $\mathrm{Se}, \mathrm{Zn}, \mathrm{Mn}$ and $\mathrm{Cu}$ were $80 \%, 20 \%, 17 \%$ and $5.6 \%$, respectively. 
Table 6 Estimated dietary intake (EDI) of the essential element (Se, $\mathrm{Zn}, \mathrm{Mn}$ and $\mathrm{Cu}$ ) in $\mathbf{2 5}$ samples of the four food types (rice, wheat, meat and chicken)

\begin{tabular}{lcccc}
\hline \multicolumn{6}{l}{ EDI of the essential elements $(\boldsymbol{\mu g} / \mathbf{k g}$ bw/day) } \\
\hline Food type & Se & Zn & Mn & Cu \\
\hline Rice & 0.46 & 32.56 & 35.41 & 2.81 \\
Wheat & 0.20 & 20.03 & 25.88 & 1.55 \\
Meat & 0.17 & 32.38 & 0.48 & 0.48 \\
Chicken & 1.81 & 52.81 & 3.14 & 4.95 \\
Total & 2.64 & 137.78 & 64.91 & 9.79 \\
\hline
\end{tabular}

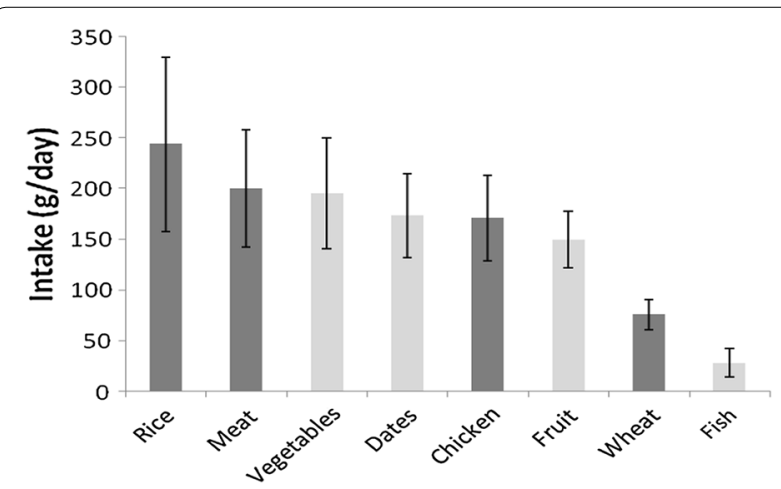

Fig. 2 Average daily intakes of foods by food group in the Najranian population total diet (dark grey) food groups investigated in this study; (light grey), food groups not investigated in this study. The values are means, with standard deviations represented by vertical bars

\section{Discussion}

This study was carried out to determine the EDI of essential elements ( $\mathrm{Se}, \mathrm{Zn}, \mathrm{Mn}$ and $\mathrm{Cu}$ ) from four selected staple foods (rice, wheat, meat and chicken) of a population in Najran city, Saudi Arabia. This study provides valuable nutritional risk assessment based on EDIs of the essential elements in this population. There is a little information available regarding the EDIs of essential elements in the main four selected staple foods in Saudi Arabia including Najran city.

\section{Concentration of essential elements in four selected foods}

The results of this study showed the concentrations of the elements in all food samples (rice, wheat, meat and chicken) as follows: Se $(0.07-0.24 \mathrm{mg} / \mathrm{kg}), \mathrm{Zn}(3.91-$ $20.89 \mathrm{mg} / \mathrm{kg}), \mathrm{Mn}(0.63-14.89 \mathrm{mg} / \mathrm{kg})$ and $\mathrm{Cu}(0.69-$ $2.41 \mathrm{mg} / \mathrm{kg}$ ). The range of concentration of the elements in all the food samples in our study is within the range of the WHO recommended limits [44].

\section{Essential elements in rice}

In this study, the mean level of concentrations $(\mathrm{mg} / \mathrm{kg})$ of all rice samples for $\mathrm{Se}, \mathrm{Zn}, \mathrm{Mn}$ and $\mathrm{Cu}$ were 0.07, 3.91, 4.32 and 1.44, respectively. Our results for rice samples were lower than the results, except for Se, from a study in Bangladesh that had measured the mean concentrations $(\mathrm{mg} / \mathrm{kg})$ levels of essential elements in rice Se (0.03), $\mathrm{Zn}$ (13.18), Mn (4.65) and $\mathrm{Cu}$ (1.99) [45]. Our results differ from the findings of a study from Sweden, which found concentrations $(\mathrm{mg} / \mathrm{kg})$ for Se (0.10), $\mathrm{Zn} \mathrm{(15.00),} \mathrm{Mn}$ (16.00) and $\mathrm{Cu}$ (1.90) [46]. We detected lower concentrations for all the measured elements compared to the latter study. Our findings are similar to the results of a study on rice samples from Qatar market, which had found the concentrations level for Se to be in the range 0.006$0.42 \mathrm{mg} / \mathrm{kg}$ [43]. Moreover, their $\mathrm{Zn} \mathrm{(2.79-29.90} \mathrm{mg/}$ $\mathrm{kg}$ ) concentration was similar to our rice samples. The variances noted in results between our study and other studies from the literature could be attributed to several factors such as the water used in irrigation as well as the type of soil where the rice was cultivated etc. [47].

\section{Essential elements in wheat}

The findings of this study reveal that the mean concentrations $(\mathrm{mg} / \mathrm{kg})$ of Se (0.04), Zn (11.19), Mn (14.69) and $\mathrm{Cu}(2.41)$ in wheat samples were all lower than recommended WHO values [44]. A study in Bangladesh analysed 30 different kinds of wheat by ICP-MS reported the concentrations level of Se $(1.894 \mathrm{mg} /$ $\mathrm{kg}), \mathrm{Zn}(0.245 \mathrm{mg} / \mathrm{kg}), \mathrm{Mn}(0.0012 \mathrm{mg} / \mathrm{kg})$ and $\mathrm{Cu}$ $(0.209 \mathrm{mg} / \mathrm{kg})$ [45]. The authors suggested that these levels posed no health risks to human [45]. Another study on wheat grains from Iran had reported lower concentrations of $\mathrm{Cu}(0.86 \pm 0.19 \mathrm{mg} / \mathrm{kg})$ and $\mathrm{Zn}$ $(1.39 \pm 0.5 \mathrm{mg} / \mathrm{kg})$ than our values. Both reported values were below the WHO standard [44, 48]. Moreover, geographic differences between samples and nature of soil and water can cause variation among results of different studies [49]. Also, the concentrations of elements detected do not exceed the recommended values of the WHO [44].

\section{Essential elements in meat}

For the meat samples, the mean concentrations (mg/ $\mathrm{kg}$ ) were as follows: Se (0.12), Zn (20.89), Mn (0.95) and $\mathrm{Cu}$ (1.71). A recent study from Australia on sheep meat found that the concentrations for $\mathrm{Cu}$ was $0.74 \mathrm{mg} / \mathrm{kg}$ [50]. Their results $(\mathrm{mg} / \mathrm{kg})$ for muscle, liver and kidneys were $0.014,1.05$ and 0.44 for $\mathrm{Zn}$, respectively. The mean levels $(\mathrm{mg} / \mathrm{kg})$ for Se in muscle, was 0.09 [50]. Their results are similar to our results except for $\mathrm{Zn}$ which is lower than ours. Another study 
on essential elements in red meat, in the Canary Islands (Spain), found the mean concentrations of $\mathrm{Cu}$ (0.87 mg/kg), Zn (33.15 mg/kg) and Mn (0.11 mg/kg). With the exception of $\mathrm{Zn}$, these are all lower than our results. The concentrations of the elements in these studies were not exceeding the international limits and posed no health risks $[44,51]$. Our study for cooked meat varies from the results of a study in Brazil, on beef meat cooked in water that had found the concentrations $(165 \pm 2 \mathrm{mg} / \mathrm{kg})$ for $\mathrm{Zn}$ and $(1.2 \pm 0.6 \mathrm{mg} / \mathrm{kg})$ for $\mathrm{Cu}$ [52]. Compared to the latter study, the concentration of $\mathrm{Zn}$ was higher than our results, while the $\mathrm{Cu}$ levels were similar to our results. Despite the fact that our study and other studies discussed here were for cooked meat, one might argue that differences in the concentration of elements can be attributed to differences in the type of food used in feeding the animals as well as differences in age and environment [53].

\section{Essential elements in chicken}

The results of this study showed that in all the studied chicken samples, the mean concentrations $(\mathrm{mg} / \mathrm{kg})$ of the essential elements of Se (0.24), Zn (7.21), Mn (0.63) and $\mathrm{Cu}$ (0.69), respectively. The findings of our study were within the ranges of the results of a study from Turkey on chicken samples that determined the concentration of $\mathrm{Cu}$ $(0.10-114 \mathrm{mg} / \mathrm{kg})$, Se $(0.10-0.91 \mathrm{mg} / \mathrm{kg})$ and $\mathrm{Mn}(0.05-$ $3.91 \mathrm{mg} / \mathrm{kg})$. They concluded that their results were within the recommended limit and posed no risk for human consumption [54]. In a recent study from Brazil, it was found that the concentrations of different elements in chicken samples were $0.65 \pm 0.1 \mathrm{mg} / \mathrm{kg}$ and $29 \pm 1 \mathrm{mg} /$ $\mathrm{kg}$ for $\mathrm{Cu}$ and $\mathrm{Zn}$, respectively [52]. Their results showed that $\mathrm{Cu}$ was similar to our results and $\mathrm{Zn}$ was higher than ours. These differences indicate that chicken samples originating from different locations can have widely different elemental contents, which could be due to nature of the feeding ingredients as well as the difference in age and environment [55].

\section{Daily intake (DI)}

This study results showed that the daily intake (DI) of $\mathrm{Se}, \mathrm{Zn}, \mathrm{Mn}$ and $\mathrm{Cu}$ in the four food types (rice, wheat, meat and chicken) varies widely. The mean daily intake $(\mu \mathrm{g} /$ day $)$ for essential elements in rice, wheat, meat and chicken were Se (6.83-41.12), Zn (949.02-4173.55), Mn (106.87-2365.15) and $\mathrm{Cu}$ (118.12-387.51), respectively (Table 5). There are difference and similarity between our study findings and other studies in the literature [56, 57]. These variations in the result could be due to the fact only four types of foods were investigated in our study, while other studies investigated many different types of food categories or carried out a total diet study. In the future more studies are needed to assess the total daily intake of essential elements in Najran by including other foods not included in our study.

\section{Estimated dietary intake (EDI) and recommended daily allowance (RDA)}

The findings of this study showed the range of EDI (mg/ $\mathrm{kg}$ bw/day) of the essential elements vary widely in the main four staple foods rice, wheat, meat and chicken. It is not possible to directly compare our EDI to those reported in the literature since our study was based on the intake from only four types of foods. The variations in the EDI between our study and other studies from Qatar, Korea, Saudi Arabia, Spain and Italy can be attributed to different factors [56, 58-61]. For example, the condition of the soil, water used for irrigation and content of minerals in animal feed is unlikely to be similar between different countries, and it affects the level of concentration of these elements on the main staple foods of these countries [62]. Other factors may be because of environmental factors such as for example growing rice in polluted soils [63]. Additionally, the quantities of main staple foods that are commonly consumed vary among different populations, which will also lead to differences in the EDI. Besides, other studies have included more food types (for example thirteen food types) [58], whereas in this study we only focused on four staple foods consumed in one city (Najran) in Saudi Arabia. Moreover, our study was focused on two food categories, cereal (rice and wheat) and meat (poultry and red meat).

We focused on determining if the four foods analysed in this study provides sufficient quantities of the essential elements to meet the daily requirements. The four staple foods in this study contribute to PMTDI with the following percentages related to the essential elements; Se (13\%), $\mathrm{Zn}(11 \%), \mathrm{Mn}(14 \%)$ and $\mathrm{Cu}(3.4 \%)$ as presented in Fig. 1. The PMTDI of these four elements shows no risk of exposure to excess of essential elements from the four foods investigated.

The percentage of the recommended daily allowance (RDA) for $\mathrm{Se}, \mathrm{Zn}, \mathrm{Mn}$ and $\mathrm{Cu}$ were $79.8 \%, 20.1 \%, 17.7 \%$ and $5.6 \%$, respectively. Se represents almost about $80 \%$ of the RDA from the four foods. It is highly likely that the population in Najran should be able to receive the remaining $20 \%$ of the $\mathrm{RDA}$ from other foods that were not investigated in this study but are rich in Se including cruciferous vegetables, fruits and seafood [64]. The RDA estimated in our study for $\mathrm{Zn}$ was $20 \%$, which means $80 \%$ of $\mathrm{Zn}$ will need to be derived from other foods to avoid deficiency of this important element among Najran population. This needs to be investigated in the future to check if there is a possibility of $\mathrm{Zn}$ deficiency. If $\mathrm{Zn}$ intake is low in the population, after a total diet or human 
biomonitoring study, the population will need to consume foods that are rich in this element such as milk and dairy products, legumes and seafood $[65,66]$.

Concerning $\mathrm{Mn}$, the four investigated staple foods provided only $17 \%$ of the RDA. Thus, people will need to obtain the remaining amount of the total RDA from other foods that are rich in Mn. In addition to meat and poultry, Mn can be found in foods such as grains, tea, nuts and fish $[66,67]$. However, it is known from our food frequency questionnaire in this study that the Najran people do not consume a high amount of fish. Therefore, people in Najran could obtain $\mathrm{Zn}$ and Mn by increasing their consumption of other foods such as fish and vegetables. Further, in our study, we estimated that only $5.4 \%$ of the RDA of $\mathrm{Cu}$ is derived from the four staple foods investigated. This value is very low compared to the international RDA set by the WHO [68]. The low intake of $\mathrm{Cu}$ from these foods may lead to a possibility of a deficiency of $\mathrm{Cu}$ in the Najran population. There are some disease that are prevalent in the population that may be linked to $\mathrm{Cu}$ deficiency such as anemia [69]. A study by Al Faran et al. [70] had reported that anemia is highly prevalent among adults pregnant and nonpregnant women in Najran area. Also, another study by Al-Muhaimeed et al. [71] had confirmed that the prevalence of sickle cell disease in Najran is higher than some other part of Saudi Arabia. This could be due to socioeconomic, educational level and dietary reasons [74]. $\mathrm{Cu}$ deficiency can be avoided by consuming foods that are rich in $\mathrm{Cu}$ from other sources including, but not limited to, drinking water, tea, apple juice, milk, meat-poultry, eggs and cereals [75].

To obtain a full picture of the EDIs and RDAs, a comprehensive study is needed in the future by including the analysis of other foods that were not investigated in the current study (for example vegetables, fruits, fish and water). Such kind of study may help the public health professionals and policymakers to advise people on the healthy nutrition and how they can obtain an optimum intake of the essential elements.

\section{Conclusion}

This is the first study to have determined the intake of essential elements $(\mathrm{Cu}, \mathrm{Zn}, \mathrm{Mn}$ and $\mathrm{Se})$ from foods in a population from Najran by combining data from a food frequency questionnaire with analysis of foods using ICP-MS. The content of these four essential elements, in four commonly consumed foods (rice, wheat, meat and chicken), was determined. The EDIs for the measured essential elements in the foods analysed in this study did not exceed the recommended values set by WHO. The highest EDIs for measured essential elements from the four investigated foods were $\mathrm{Cu}$ and $\mathrm{Mn}$ from wheat, Se from Chicken and $\mathrm{Zn}$ from meat. However, the lowest EDIs input was Se from wheat, $\mathrm{Zn}$ from rice, and both $\mathrm{Mn}$ and $\mathrm{Cu}$ from Chicken. The four investigated foods altogether provided a relatively high percentage of RDA for Se, however, the \% RDA for $\mathrm{Mn}, \mathrm{Cu}$ and $\mathrm{Zn}$ were quite low. The results of this study are beneficial for the public health professionals and provide a basis for further examining the diet of the population in Najran in more detail in order to develop safety policies and to evaluate health risk related to dietary intake of essential elements. A total intake of elements from different foods in Najran as well as human biomonitoring studies will be considered in the future.

\section{Abbreviations}

BW: body weight; CC: calculated concentration; Cu: copper; DI: daily intake; EDI: estimated dietary intake; EDIs: estimated dietary intakes; FFQ: food frequency questionnaire; HQ: hazard quotient; HDL: high density lipoprotein; ICP-MS: inductively coupled plasma-mass spectrometry; ICP-OES: inductively coupled plasma optical emission spectrometry; Mn: manganese; PMTDI: provisional maximum tolerable daily intake; PTDI: provisional tolerable daily intakes; RDA: recommended daily allowance; SAR: Saudi Arabia Riyals; Se: selenium; WHO: World Health Organization; Zn: zinc.

\section{Acknowledgements}

The authors EIB and HM extend their appreciation to the Deanship of Scientific Research at King Khalid University for funding this work through research groups program under grant number R.G.P.1/7/40. The authors would like to express their gratitude to Chemistry Department, College of Sciences, King Khalid University, for providing administrative and technical support. Thanks, due to Dr. Saad Alqahtani, Mr. Nasser Al Harthi, Mr. Abubaker Al Harthi, Mr. Yahya Al Abbas of Najran University, College of Pharmacy and to Mr. Abubaker A. Younis of Al-Ghad International Colleges for Medical Sciences, Najran for helping during samples collection. We also thank the laboratory's staff in Municipality of Khamis Mushayt for their cooperation and helping in samples preparation. Finally, the authors thank all respondents to this study.

\section{Authors' contributions}

$\mathrm{HM}, \mathrm{PIH}$ and EIB are participated in the design of the study, and drafted the manuscript. HM and EIB carried out the analytical and instrumental experiments. ElB performed the statistical analysis. All authors read and approved the final manuscript.

\section{Funding}

A fund was received for this study from King Khalid University Grant Number R.G.P.1/7/40.

Availability of data and materials

The data that support the findings of this study are available from the corresponding author (E.B.) upon reasonable request.

\section{Competing interests}

The authors declare that they have no competing interests.

\section{Author details \\ ${ }^{1}$ Faculty of Health and Life Science, De Montfort University, Leicester LE1 9BH, UK. ${ }^{2}$ Department of Chemistry, College of Science, King Khalid University, Abha 61413, Saudi Arabia.}

Received: 11 October 2018 Accepted: 7 May 2019

Published online: 27 May 2019 


\section{References}

1. Blaney S, Beaudry M, Latham M, Thibault M (2009) Nutritional status and dietary adequacy in rural communities of a protected area in Gabon. Public Health Nutr 12(10):1946-1959

2. Vorster HE, Bourne LT (2016) The nutrition transition in developing countries. Community Nutr Dev Ctries 54:871-873

3. Oliver MA, Gregory PJ (2015) Food security and human health: a review. Eur J Soil Sci 66:257-276

4. Prashanth L, Kattapagari KK, Chitturi RT, Baddam VRR, Prasad LK (2015) A review on the role of essential trace elements in health and disease. J Dr NTR Univ Health Sci 4(1):75-78

5. Mozrzymas R (2018) Trace elements in human health. Recent Adv Trace Elem 26:373-402

6. Gharibzahedi SM, Jafari SM (2017) The importance of minerals in human nutrition: bioavailability, food fortification, processing effects and nanoencapsulation. Trends Food Sci Technol 62:119-132

7. Abdel-Aziz SM, Abdel-Aziz MS, Garg N (2016) Health benefits of trace elements in human diseases. Microb Food Health 1:117-142

8. Navarro-Alarcon M, Cabrera-Vique C (2008) Selenium in food and the human body: a review. Sci Total Environ 400(3):115-141

9. Chen X, Young G, Chen J, Chen J, Chen X, Wen Z, Ge K (1980) Studies on the relations of selenium and Keshan diseases. Biol Trace Elem Res 2(2):91-107

10. dos Reis AR, El-Ramady H, Santos EF, Gratão PL, Schomburg L (2017) Overview of selenium deficiency and toxicity worldwide: affected areas, selenium-related health issues, and case studies. Selenium Plants 6:209-230

11. Stoffaneller R, Morse NL (2015) A review of dietary selenium intake and selenium status in Europe and the Middle East. Nutrients 7(3):1494-1537

12. Gunasekara P, Hettiarachchi M, Liyanage C, Lekamwasam S (2011) Effects of zinc and multimineral vitamin supplementation on glycemic and lipid control in adult diabetes. Diabetes Metab Syndr Obes 4:53-60

13. Prasad AS (2014) Impact of the discovery of human zinc deficiency on health. J Trace Elem Med Biol 28(4):357-363

14. Gupta UC, Gupta SC (2014) Sources and deficiency diseases of mineral nutrients in human health and nutrition: a review. Pedosphere 24(1):13-38

15. Aschner JL, Aschner M (2005) Nutritional aspects of manganese homeostasis. Mol Asp Med 26(5):353-362

16. Al-Bitar Y, Azam JS, Azam T (2005) Menke's kinky hair syndrome-a rare medical condition. J Pak Med Assoc 55:40-42

17. Wazir SM, Ghobrial I (2017) Copper deficiency, a new triad: anemia, leucopenia, and myeloneuropathy. J Community Hosp Intern Med Perspect $7: 265-268$

18. Muthayya S, Sugimoto JD, Montgomery S, Maberly GF (2014) An overview of global rice production, supply, trade, and consumption. Ann NY Acad Sci 1324(1):7-14

19. Prasad V, Strömberg CAE, Leaché AD, Samant B, Patnaik R, Tang L, Mohabey DM, Ge S, Sahni A (2011) Late cretaceous origin of the rice tribe provides evidence for early diversification in Poaceae. Nat Commun 2:480-487

20. Von Braun J (2008) The world food situation: new driving forces and required actions, vol 6. Food and Agriculture Organization of the United Nations, FAO/UN, Washington, pp 169-172. http://agris.fao.org/agris -search/search.do?recordID=GB2013203274. Accessed May 2018

21. Zhang Z, Kane J, Liu AY, Venn BJ (2016) Benefits of a rice mix on glycaemic control in Asian people with type 2 diabetes: a randomised trial. Nutr Diet 73(2):125-131

22. USDA Foreign Agricultural Service (2013) GAIN report, vol 3. pp 117-123

23. Barron C, Holopainen-Mantila U, Sahlstrom S, Hotekjolen AK, LullienPellerin V (2017) Assessment of biochemical markers identified in wheat for monitoring barley grain tissue. J Cereal Sci 74:11-18

24. Wrigley CW (2016) Wheat: an overview of the grain that provides' our daily bread, vol 4. pp 105-116

25. Scibilia J, Pastorello EA, Zisa G, Ottolenghi A, Bindslev-Jensen C, Pravettoni V, Scovena E, Robino A, Ortolani C (2006) Wheat allergy: a double-blind, placebo-controlled study in adults. J Allergy Clin Immuno 117(2):433-439

26. Adam SO, Khan IM (2014) Nutrition and food consumption patterns in the Kingdom of Saudi Arabia. Pak J Nutr 13(4):81-190
27. Elmadfa I, Meyer AL (2017) Animal proteins as important contributors to a healthy human diet. Annu Rev Anim Biosci 5:111-131

28. Micha R, Wallace SK, Mozaffarian D (2010) Red and processed meat consumption and risk of incident coronary heart disease, stroke, and diabetes mellitus: a systematic review and meta-analysis. Circulation 121(21):2271-2283

29. Li SW, He Y, Zhao HJ, Wang Y, Liu JJ, Shao YZ, Li JL, Sun X, Zhang LN, Xing MW (2017) Assessment of 28 trace elements and 17 amino acid levels in muscular tissues of broiler chicken (Gallus gallus) suffering from arsenic trioxide. Ecotoxicol Environ Saf 144:430-437

30. Bortolaia V, Espinosa-Gongora C, Guardabassi L (2016) Human health risks associated with antimicrobial-resistant enterococci and Staphylococcus aureus on poultry meat. Clin Microbiol Infect 22(2):130-140

31. Selvanathan S, Selvanathan EA, Albalawi S, Hossain M (2016) Meat and fish consumption patterns in Saudi Arabia. Appl Econ 48(5):446-460

32. Al-Daghri NM, Al-Attas OS, Alokail MS, Alkharfy KM, Yousef M, Sabico SL, Chrousos GP (2011) Diabetes mellitus type 2 and other chronic non-communicable diseases in the central region, Saudi Arabia (Riyadh cohort 2): a decade of an epidemic. BMC Med 9(1):76-81

33. Khayri HO, Muneer SE, Babiker EE (2017) Gender inequality and nutritional status in patriarchal societies: the case of primary school students in Riyadh City, Saudi Arabia. Adv Obes Weight Manag Control 6(3):165-171

34. Shori AB, Albaik M, Bokhari FM (2017) Fast food consumption and increased body mass index as risk factors for weight gain and obesity in Saudi Arabia. Obes Med 1(8):1-5

35. Houghton SC, Manson JE, Whitcomb BW, Hankinso SE, Troy LM, Bigelow C, Bertone-Johnson ER (2018) Carbohydrate and fiber intake and the risk of premenstrual syndrome. Eur J Clin Nutr 29(6):861-867

36. Al-Ahmary KM (2009) Selenium content in selected foods from the Saudi Arabia market and estimation of the daily intake. Arab J Chem 1(2):95-99

37. Al-Othman ZA, Yilmaz E, Sumayli HM, Soylak M (2012) Evaluation of trace metals in tea samples from Jeddah and Jazan, Saudi Arabia by atomic absorption spectrometry. Bull Environ Contam Toxicol 1:1216-1219

38. Mohamed H, Haris PI, Brima El (2017) Estimated dietary intakes of toxic elements from four staple foods in Najran city, Saudi Arabia. Int J Environ Res Publ Health 14(12):1575-1579

39. Thuvander A, Möller T, Enghardt Barbieri H, Jansson A, Salomonsson AC, Olsen M (2001) Dietary intake of some important mycotoxins by the Swedish population. Food Addit Contam 18(8):696-706

40. Kirk MD, Pires SM, Black RE (2010) World Health Organization estimates of the global and regional disease burden of four foodborne chemical toxins, 2010: a data synthesis. PLoS Med 12(12):1940-1946

41. Hald T, Aspinall W, Devleesschauwer B (2016) World Health Organization estimates of the relative contributions of food to the burden of disease due to selected foodborne hazards: a structured expert elicitation. PLoS ONE 11(1):45839-45841

42. WHO Expert Committee on Biological Standardization (2013) Meeting and World Health Organization. WHO expert committee on biological standardization: sixtieth report. World Health Organization, Geneva (online) published, pp 977-979

43. WHO Expert Committee on Biological Standardization (2013) Meeting and World Health Organization. WHO expert committee on biological standardization: sixty-third report. World Health Organization, Geneva (online) published, pp 980-983

44. World Health Organization (2009) Evaluation of certain food additives: sixty-ninth report of the Joint FAO/WHO Expert Committee on Food Additives, vol 45. World Health Organization, Geneva (online) published, pp 65-69

45. Ahmed MK, Shaheen N, Islam MS, Habibullah-Al-Mamaun M, Islam S, Banu CP (2015) Trace elements in two staple cereals (rice and wheat) and associated health risk implications in Bangladesh. Environ Monit Assess 187(6):326-331

46. Jorhem L, Åstrand C, Sundström B, Baxter M, Stokes P, Lewis J, Grawe KP (2008) Elements in rice on the Swedish market: part 2. Chromium, copper, iron, manganese, platinum, rubidium, selenium and zinc. Food Addit Contam Part A Chem Anal Control Expo Risk Assess 25(7):841-850

47. Lu Y, Song S, Wang R, Liu Z, Meng J, Sweetman AJ, Jenkins A, Ferrier RC, Li H, Luo W, Wang T (2005) Impacts of soil and water pollution on food safety and health risks in China. Environ Int 77:5-15 
48. Kahkha MRR, Bagheri S, Noor R, Pire J, Java S (2017) Examining total concentration and sequential extraction of heavy metals in agricultural soil and wheat. Pol J Environ Stud 26(5):5-11

49. Liu H, Wei Y, Zhang Y, Wei S, Zhang S, Guo B (2017) The effectiveness of multi-element fingerprints for identifying the geographical origin of wheat. Int J Food Sci Technol 52(4):1018-1025

50. MacLachlan DJ, Budd K, Connolly J, Derrick J, Penrose L, Tobin T (2016) Arsenic, cadmiium, cobalt, copper, lead, mercury, molybdenum, selenium and zinc concentrations in liver, kidney and muscle in Australian sheep. J Food Compos Anal 50:97-107

51. González WD, Caballero A, Carlson L, Hernández F, Gutiérrez AJ (2014) Determination of iron, copper, zinc and manganese in sausage, poultryrabbit meat, viscera and red meats consumed by the population in the Canary Islands, Spain. J Toxins 1(1):7-11

52. Eveline A, Aline F, Celia J, Gilberto B (2017) Bio accessibility of Ca, Cu, $\mathrm{Fe}, \mathrm{Mg}, \mathrm{Zn}$, and crude protein in beef, pork and chicken after thermal processing. Food Chem 3:111-117

53. Pereira V, López-Alonso M, Miranda M, Benedito لlL, García-Vaquero M (2017) Relationship between the essential and toxic element concentrations and the proximate composition of different commercial and internal cuts of young beef. Eur Food Res Technol 1(10):1-5

54. Uluozlu OD, Tuzen M, Mendil D, Soylak M (2009) Assessment of trace element contents of chicken products from Turkey. J Hazard Mater 163(2):982-987

55. Ghalkhanbaz M, Shariatmadari F, Karimi Torshizi MA (2018) Effects of different levels of trace minerals premix in finisher diets on performance, immune system and meat lipid oxidation of chicken fed barley-or wheatbased diet. J Appl Anim Res 2(1):46-51

56. Rowell C, Kuiper N, Al-Saad K, Nriagu J, Shomar BA (2014) Market basket survey of As, Zn and Se in rice imports in Qatar: health implications. Food Chem Toxicol 31:33-39

57. Santos EE, Lauria DC, Da Silveira CP (2004) Assessment of daily intake of trace elements due to consumption of foodstuffs by adult inhabitants of Rio de Janeiro city. Sci Total Environ 327(3):69-79

58. Choi Y, Kim J, Lee HS (2009) Selenium content in representative Korean foods. J Food Compos Anal 22(2):117-122

59. Mahboob S, Alkkahem Al-Balwai HF, Al-Misned F, Al-Ghanim KA, Ahmad Z (2014) A study on the accumulation of nine heavy metals in some important fish species from a natural reservoir in Riyadh, Saudi Arabia. Toxicol Environ Chem 96(5):783-798

60. Rubio C, Gutiérrez ÁJ, Revert C, Reguera J, Burgos A, Hardisson A (2009) Daily dietary intake of iron, copper, zinc and manganese in a Spanish population. Int J Food Sci Nutr 60(7):590-600

61. Filippini T, Cilloni S, Malavolti M, Violi F, Malagoli C, Tesauro M, Bottecchi I, Ferrari A, Vescovi L, Vinceti M (2018) Dietary intake of cadmium, chromium, copper, manganese, selenium and zinc in a Northern Italy community. J Trace Elem Med Biol 5:110-115
62. Yami SG, Chandravanshi BS, Wondimu T, Abuye C (2016) Assessment of selected nutrients and toxic metals in fruits, soils and irrigation waters of Awara Melka and Nura Era farms, Ethiopia. Springer Plus 5(1):1-12

63. Rayman MP (2008) Food-chain selenium and human health: emphasis on intake. Br J Nutr 100(2):254-268

64. Keck AS, Finley JW (2004) Cruciferous vegetables: cancer protective mechanisms of glucosinolate hydrolysis products and selenium. Integr Cancer Ther 3(1):5-12

65. Roohani N, Hurrell R, Kelishadi R, Schulin R (2013) Zinc and its importance for human health: an integrative review. J Res Med Sci 18(2):144

66. Trumbo P, Yates AA, Schlicker S, Poos M (2001) Dietary reference intakes: vitamin A, vitamin $\mathrm{K}$, arsenic, boron, chromium, copper, iodine, iron, manganese, molybdenum, nickel, silicon, vanadium, and zinc. J Am Diet Assoc 101(1):294-301

67. Pennington JA, Schoen SA, Salmon GD (1995) Composition of core foods of the US food supply, 1982-1991: III. Copper, manganese, selenium, and iodine. J Food Compos Anal 8(3):171-217

68. World Health Organization (1996) Trace elements in human nutrition and health (NLM Classification: QU130). World Health Organization, Geneva, pp 78-81. ISBN 924-1-56173-4

69. Warady BA (2017) Anemia management. Pediatr Dial Case Stud 7:179-185

70. Alfaran F, Aldosari S (2017) Adults hemoglobin level in Atiafa primary health care center in Najran Area (5-7)/1433 H. IJIRMS 2(2):509-520

71. Al-Muhaimeed $H$, Thomas G, Divakarn MP, Al Sedran N (2000) Pattern of hearing loss in sickle cell disease. Aust J Oto-Laryngol 3(5):472-473

72. Alfawaz HA, Khan N, AlOteabi N, Hussain SD, Al-Daghri NM (2017) Factors associated with dietary supplement use in Saudi pregnant women. Reprod Health 14(1):104-116

73. Farajvand M, Kiarostami V, Davallo M, Ghaedi A (2018) Optimization of solvent terminated dispersive liquid-liquid microextraction of copper ions in water and food samples using artificial neural networks coupled bees algorithm. Bull Environ Contam Toxicol 100(3):402-408

74. Joint F.A.O, World Health Organization (1998) Carbohydrates in human nutrition: report of a joint FAO/WHO expert consultation, Rome, 14-18 April 1997. In: Carbohydrates in human nutrition: report of a joint FAO/ WHO expert consultation, Rome (online) published 14-18 April 1997, pp 121-125

75. EPA. Environmental Protection Agency, Integrated Risk Information System (2001) IRIS from US. http://www.epa.govyirisygloss8.htm. Accessed April 2018, pp 115-119

\section{Publisher's Note}

Springer Nature remains neutral with regard to jurisdictional claims in published maps and institutional affiliations.
Ready to submit your research? Choose BMC and benefit from:

- fast, convenient online submission

- thorough peer review by experienced researchers in your field

- rapid publication on acceptance

- support for research data, including large and complex data types

- gold Open Access which fosters wider collaboration and increased citations

- maximum visibility for your research: over $100 \mathrm{M}$ website views per year

At BMC, research is always in progress.

Learn more biomedcentral.com/submissions 